\title{
Peptide-mediated Inactivation of Recombinant and Platelet Plasminogen Activator Inhibitor-1 In Vitro
}

\author{
Daniel T. Eitzman, ${ }^{\star \$}$ William P. Fay, ${ }^{\star \$ 1}$ Daniel A. Lawrence, ${ }^{\$}$ Ann Marie Francis-Chmura, ** Joseph D. Shore, ** \\ Steven T. Olson, \# and David Ginsburg \\ ${ }^{*}$ Division of Cardiology and ${ }^{\ddagger}$ Division of Human Genetics, ${ }^{8}$ Department of Internal Medicine, and the "Howard Hughes Medical \\ Institute, University of Michigan Medical Center, Ann Arbor, Michigan 48109; 'Ann Arbor Veterans Affairs Hospital, Ann Arbor, \\ Michigan 48105; **Department of Biochemistry, Henry Ford Hospital, Detroit, Michigan 48202-2689; and ${ }^{\ddagger \ddagger}$ Center for Molecular \\ Biology of Oral Diseases, University of Illinois, Chicago, Illinois 60612
}

\begin{abstract}
Plasminogen activator inhibitor-1 (PAI-1), the primary inhibitor of tissue-type plasminogen activator ( $t$-PA) and urokinase plasminogen activator, is an important regulator of the blood fibrinolytic system. Elevated plasma levels of PAI1 are associated with thrombosis, and high levels of PAI-1 within platelet-rich clots contribute to their resistance to lysis by t-PA. Consequently, strategies aimed at inhibition of PAI-1 may prove clinically useful. This study was designed to test the hypothesis that a 14-amino acid peptide, corresponding to the PAI-1 reactive center loop (residues 333-346), can rapidly inhibit PAI-1 function. PAI-1 (0.7 $\mu \mathrm{M})$ was incubated with peptide $(55 \mu \mathrm{M})$ at $37^{\circ} \mathrm{C}$. At timed intervals, residual PAI-1 activity was determined by addition of reaction mixture samples to $t-P A$ and chromogenic substrate. The $T_{1 / 2}$ of PAI-1 activity in the presence of peptide was $4 \pm 3$ min compared to a control $T_{1 / 2}$ of $98 \pm 18 \mathrm{~min}$. The peptide also inhibited complex formation between PAI1 and t-PA as demonstrated by SDS-PAGE analysis. However, the capacity of the peptide to inhibit PAI-1 bound to vitronectin, a plasma protein that stabilizes PAI-1 activity, was markedly attenuated. Finally, the peptide significantly enhanced in vitro lysis of platelet-rich clots and plateletpoor clots containing recombinant PAI-1. These results indicate that a 14-amino acid peptide can rapidly inactivate PAI-1 and accelerate fibrinolysis in vitro. These studies also demonstrate that PAI-1 function can be directly attenuated in a physiologic setting and suggest a novel approach for augmenting fibrinolysis in vivo. (J. Clin. Invest. 1995. 95:2416-2420.) Key words: fibrinolysis - thrombolysis • vitronectin • platelets $\cdot$ serpin
\end{abstract}

Address correspondence to Daniel T. Eitzman, 4520 MSRB I, University of Michigan Medical Center, 1150 West Medical Center Drive, Ann Arbor, MI 48109-0650. Phone: 313-747-4808; FAX: 313-936-2888.

Received for publication 16 August 1994 and in revised form 12 January 1995.

1. Abbreviations used in this paper: PAI, plasminogen activator inhibitor; t-PA, tissue-type plasminogen activator.

J. Clin. Invest.

(C) The American Society for Clinical Investigation, Inc.

0021-9738/95/05/2416/05 $\$ 2.00$

Volume 95, May 1995, 2416-2420

\section{Introduction}

Plasminogen activator inhibitor-1 (PAI-1), ${ }^{1}$ a serine protease inhibitor that inhibits both tissue-type plasminogen activator $(\mathrm{t}-$ PA) and urokinase plasminogen activator, is considered critical in the regulation of vascular fibrinolysis (1). Deficiency of PAI1 in humans results in an abnormal bleeding tendency (2), while elevated levels of PAI-1 have been associated with myocardial infarction (3) and deep venous thrombosis (4), suggesting that enhanced PAI-1 activity may predispose to vascular disease by limiting intravascular fibrinolysis. Consistent with a critical role of PAI-1 in fibrinolysis, PAI-1-deficient mice generated by targeted disruption of the PAI- 1 gene demonstrate an enhanced fibrinolytic capacity (5). In addition to its role in fibrinolysis, PAI-1 has also been implicated in the regulation of several other physiological, plasminogen-dependent processes, including angiogenesis, ovulation, embryogenesis, and cell migration (6).

PAI-1 is a $50-\mathrm{kD}$ glycoprotein that rapidly inhibits both t-PA and urokinase plasminogen activator by forming $1: 1$ proteaseinhibitor complexes that are enzymatically inactive (1). PAI1 is present in plasma, vascular smooth cells, and also in endothelial cells and platelets, from which its release can be induced by a variety of agonists, such as thrombin $(7,8)$. In addition to reacting with plasminogen activators, PAI-1 binds to vitronectin (9) and fibrin (10), ligands which appear to play an important role in regulating PAI-1 function. PAI-1 is released from endothelial cells in an active conformation but converts spontaneously to an inactive form that can be reactivated in vitro (11), and possibly in vivo (12). The conversion between active and latent PAI-1 conformations is believed to be mediated by a mobile reactive center loop of PAI-1, which, when exposed, results in an active inhibitor, but, when inserted into the major $\beta$-sheet $\mathrm{A}$ of PAI-1, results in conversion to an inactive, or latent, form (13).

Given the importance of PAI-1 in fibrinolysis, strategies aimed at its rapid inactivation may be of clinical utility. Consistent with this hypothesis, inhibition of PAI-1 with monoclonal antibodies has been shown to enhance fibrinolysis (14). However, as previously suggested, non-antibody-based strategies of PAI-1 inhibition are more likely to be clinically applicable (15). PAI-1 is a member of a superfamily of structurally related proteins, the serpins (serine protease inhibitors), which includes antithrombin III and $\alpha$-1-antitrypsin (16). The latter two serpins can each be inhibited by incubation with synthetic 14-amino acid peptides corresponding to their reactive center loop sequences $(17,18)$. This process is relatively slow $\left(t_{1 / 2}>1 \mathrm{~h}\right.$ at 
$\left.37^{\circ} \mathrm{C}\right)(17,18)$ and is thought to occur via insertion of the peptide into $\beta$-sheet $\mathrm{A}$, interfering with endogenous loop insertion and converting the serpin from an inhibitor to a substrate. The aim of this study is to develop a specific inhibitor of PAI1 function. As PAI-1 is the only serpin known to undergo spontaneous reactive center loop insertion resulting in a latent conformation (19), we hypothesized that a synthetic peptide would insert more rapidly in PAI-1, thus providing an efficient method for inhibiting PAI-1 function. We tested the capacity of a tetradecapeptide, based upon residues 333-346 of mature PAI-1 (designated P1-P14) to inhibit PAI-1 activity and to accelerate in vitro clot lysis. The results of these studies indicate that P1P14 inhibits PAI-1 activity much more efficiently than previously reported for analogous peptides and their corresponding serpins, and they suggest that a peptide-based strategy for inhibition of PAI-1 may prove useful in vivo.

\section{Methods}

Materials. The $N$-acetyl-tetradecapeptide, Ac-Thr-Val-Ala-Ser-Ser-SerThr-Ala-Val-Ile-Val-Ser-Ala-Arg, corresponding to the P1-P14 sequence of PAI-1, was synthesized by the University of Michigan Peptide Synthesis Facility on a multiple peptide synthesizer, (Symphony; Rainin Instrument Co., Inc., Woburn, MA) using the Fmoc (9-fluorenylmethyloxycarbonyl) strategy (18). A control $N$-acetyl-tetradecapeptide AcAsp-Arg-Val-Tyr-Ile-His-Pro-Phe-His-Leu-Leu-Val-Tyr-Ser was purchased from Bachem Biochemica (Heidelberg, Germany). Lyophilized peptides were dissolved at a concentration of $1 \mathrm{mg} / \mathrm{ml}$ in $1 \mathrm{mM} \mathrm{HCl}$ containing $1 \%$ Tween 80 , incubated $15 \mathrm{~min}$ at $70^{\circ} \mathrm{C}$, and then stored at room temperature. Recombinant PAI-1 (20) and antithrombin III (17) were purified as described previously, and recombinant, single chain tPA $(580,000 \mathrm{IU} / \mathrm{mg}$ ) was obtained from Genentech, Inc. (South San Francisco, CA). Microcon-30 filtration tubes were from Amicon (Beverly, MA). Human glu-plasminogen, human $\alpha$-thrombin, and Spectrozyme-tPA were from American Diagnostica, Inc. (Greenwich, CT). Fluorescein-labeled fibrinogen was prepared as previously described (21), and vitronectin was a gift of D. Mosher.

Inhibitor activity assays. PAI-1 $(0.7 \mu \mathrm{M})$ was incubated at $37^{\circ} \mathrm{C}$ with either P1-P14 peptide or control peptide ( $55 \mu \mathrm{M})$ in $0.1 \mathrm{M}$ Hepes;

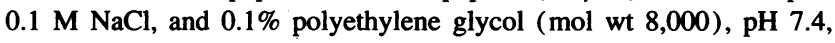
(assay buffer). At timed intervals (0-110 $\mathrm{min}), 5 \mu \mathrm{l}$ of the PAI-1peptide mixture was added to 96 well microtiter plates containing 45 $\mu \mathrm{l}$ of t-PA $(0.03 \mu \mathrm{M}$ in assay buffer $)$, and then incubated for $30 \mathrm{~min}$ at $37^{\circ} \mathrm{C}$. Spectrozyme t-PA (final concentration of $150 \mu \mathrm{M}$ ) was added to yield a final reaction vol of $70 \mu \mathrm{l}$, and $30 \mathrm{~min}$ later the absorbance at $405 \mathrm{~nm}$ was determined in a microplate reader (THERMO-max; Molecular Devices Corp., Menlo Park, CA). 100\% PAI-1 activity was defined as activity observed at time 0 , while $0 \%$ PAI-1 activity was defined as that observed in the absence of PAI-1. A standard t-PA activity curve, derived from absorbance values of varying concentrations of t-PA incubated in the absence of PAI-1, was used to determine PAI1 activity. Free peptide was removed by centrifugal ultrafiltration of reaction mixture in a microcon-30 tube (Amicon), according to manufacturer's instructions. $100 \mu \mathrm{l}$ of the PAI-1-peptide mix was subjected to centrifugation at $8,000 \mathrm{~g}$ for $10 \mathrm{~min}$. The residual $10 \mu \mathrm{l}$ of mix was diluted with an additional $100 \mu \mathrm{l}$ of assay buffer, and centrifugation was repeated. This process was repeated three times. The inhibition of elastase by $\alpha$-1-antitrypsin (22) and Factor Xa by antithrombin III were performed as previously described (23).

SDS-PAGE. SDS-PAGE was performed using a PhastSystem (Pharmacia, Uppssala, Sweden), according to manufacturer's instructions. Gels were stained with Coomassie brilliant blue.

Platelet preparations. Blood samples were collected by peripheral venipuncture from normal subjects into acid-citrate-dextrose anticoagulant $(0.8 \% \mathrm{wt} / \mathrm{vol}$ citric acid, $2.2 \%$ trisodium citrate, $2.45 \%$ dextrose) at a ratio of $6 \mathrm{vol}$ of blood to $1 \mathrm{vol}$ of anticoagulant. Donors had not consumed aspirin for at least $7 \mathrm{~d}$ before phlebotomy. Washed platelets were prepared by repeated centrifugation as previously described (21), and then resuspended in Tyrode's buffer ( $137 \mathrm{mM} \mathrm{NaCl}, 2.68 \mathrm{mM} \mathrm{KCl}$, $2 \mathrm{mM} \mathrm{CaCl}, 1 \mathrm{mM} \mathrm{MgCl}, 0.36 \mathrm{mM} \mathrm{NaH}_{2} \mathrm{PO}_{4}, 11.9 \mathrm{mM} \mathrm{NaHCO}$, $5 \mathrm{mM}$ Hepes, $0.1 \%$ glucose, and $0.35 \%$ BSA, pH 7.35).

In vitro clot lysis assays. Clot lysis assays were performed as previously described (21). A mixture of glu-plasminogen $(0.2 \mu \mathrm{M})$, fluorescein-labeled fibrinogen $(3 \mu \mathrm{M})$, and PAI-1 $(0.7 \mu \mathrm{M})$ was prepared. P1-P14 or control peptide was added to a final concentration of $55 \mu \mathrm{M}$, and clot formation was initiated by the immediate addition of $\alpha$-thrombin $(10 \mu \mathrm{M})$. t-PA $(20 \mathrm{nM})$ was added $30 \mathrm{~min}$ later, and clot lysis was allowed to occur for $60 \mathrm{~min}$ at $37^{\circ} \mathrm{C}$, after which reaction mixtures were centrifuged $(16,000 \mathrm{~g}$ for $3 \mathrm{~min})$, and $80 \mu \mathrm{l}$ of the supernatant was removed and added to $1.2 \mathrm{ml}$ of $10-\mathrm{mM}$ Tris $-\mathrm{HCl}$ and $140-\mathrm{mM} \mathrm{NaCl}$, $\mathrm{pH}$ 7.5. The fluorescence of this dilution was measured and percent clot lysis was calculated, as previously described (21).

In experiments with platelet-rich clots, platelets $\left(2.5 \times 10^{8} / \mathrm{ml}\right)$ were added as a source of PAI-1, and t-PA was added to a final concentration of $75 \mathrm{pM}$ immediately after the addition of thrombin. Clot lysis was allowed to proceed for $90 \mathrm{~min}$.

\section{Results}

Effect of P1-P14 peptide on PAI-1 activity. PAI-1 spontaneously converts from an active to an inactive, or latent, conformation with a $t_{1 / 2}$ of $1-2 \mathrm{~h}$ at $37^{\circ} \mathrm{C}(24)$. Consistent with previous data, we determined the $t_{1 / 2}$ of PAI-1 to be $98 \pm 18 \mathrm{~min}$ (mean $\pm S D$ of three experiments) under the experimental conditions described in Methods. However, addition of PAI-1 peptide $(55 \mu \mathrm{M})$ resulted in a 24-fold shortening of the PAI-1 $t_{1 / 2}$ to $4.0 \pm 3.0 \mathrm{~min}$. In contrast, a control tetradecapeptide, at the same concentration, did not affect the PAI-1 $t_{1 / 2}$ (Fig. $1 A$ ). Control reactions confirmed that neither peptide had any direct effect on t-PA activity. To separate free peptide from PAI-1, the PAI1 -peptide mixture was subjected to centrifugal ultrafiltration with a filter designed to separate molecules $<30 \mathrm{kD}$. PAI-1 remained completely inactivated after this procedure (Fig. $1 B$ ).

Since vitronectin binds and stabilizes the active conformation of PAI-1, we examined the capacity of the PAI-1 peptide to inactivate vitronectin-bound PAI-1. PAI-1 $(0.7 \mu \mathrm{M})$ was incubated with vitronectin $(1.7 \mu \mathrm{M})$ for $30 \mathrm{~min}$ at $37^{\circ} \mathrm{C}$, and then P1-P14 or control peptide $(55 \mu \mathrm{M})$ was added, and the PAI-1 $t_{1 / 2}$ was determined. In the presence of vitronectin, the $t_{1 / 2}$ of PAI-1 was prolonged $\sim$ twofold (98 $\pm 18-190 \pm 12 \mathrm{~min}$ ), similar to previous reports (25). However, in contrast to experiments with free PAI-1, the $t_{1 / 2}$ of vitronectin-bound PAI-1 was shortened only 1.6-fold by P1-P14 peptide (to $120 \pm 25 \mathrm{~min}$, Fig. $1 C$ ).

To determine whether this inhibitory effect was specific for PAI-1, the peptide was tested against other serpins, $\alpha-1$ antitrypsin and antithrombin III. No peptide inhibition of $\alpha-1$ antitrypsin or antithrombin III was observed, even under conditions where PAI-1 was completely inactivated (Fig. 2).

Effect of P1-P14 peptide on $t-P A-P A I-1$ complex formation. SDS-PAGE was performed to determine the effect of P1P14 peptide on t-PA-PAI-1 complex formation in the presence and absence of vitronectin. Although control tetradecapeptide did not prevent formation of SDS stable PAI-1-t-PA complexes, no t-PA-PAI-1 complex formation was observed when PAI-1 was preincubated for 15 min with P1-P14 peptide. Consistent with the above kinetic data, vitronectin-bound PAI-1 retained the capacity to form complexes with t-PA after treat- 

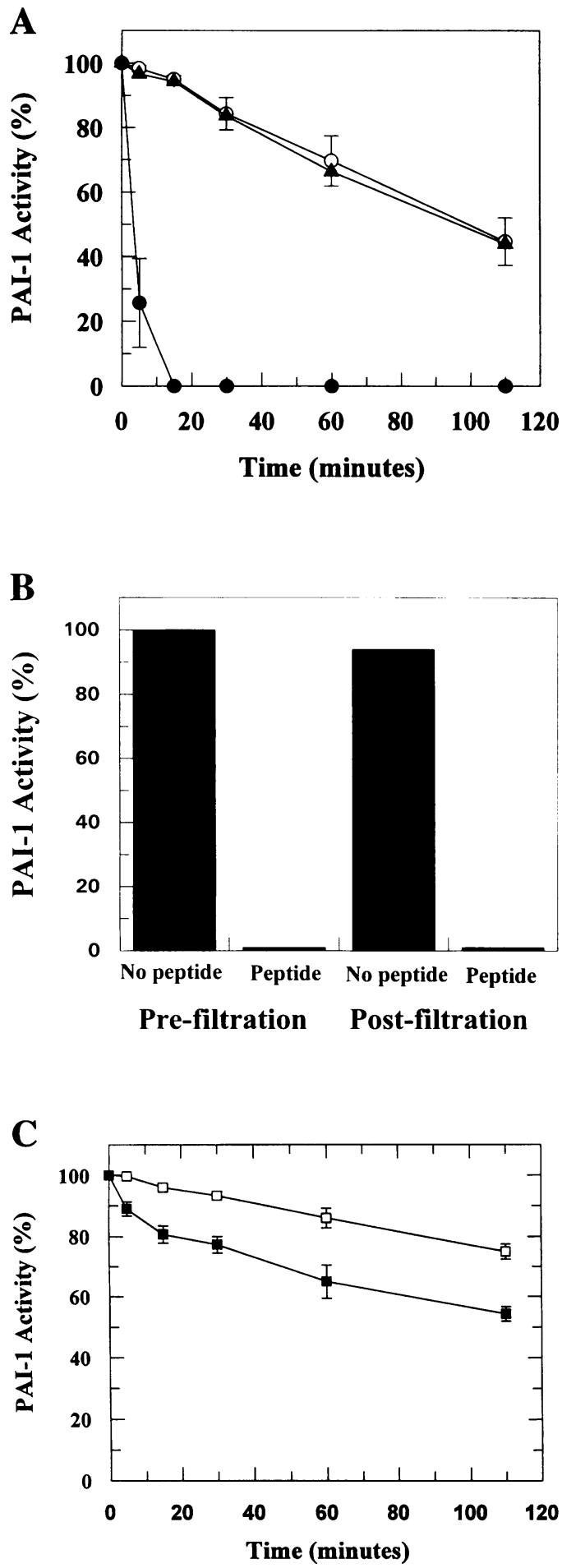

Figure 1. Inhibition of PAI-1 activity by $\mathrm{P} 1-\mathrm{P} 14$ peptide. (A) Free PAI1: PAI-1 $(0.7 \mu \mathrm{M})$ was incubated with peptide $(55 \mu \mathrm{M})$ at $37^{\circ} \mathrm{C}$. At the indicated time intervals, residual PAI- 1 activity was determined as described in Methods. O, PAI-1 alone; •, PAI-1 + P1-P14 peptide; $\mathbf{\Delta}$ PAI-1 + control peptide. Values are expressed as mean \pm SEM of three experiments. ( $B$ ) PAI-1-P1-P14 filtration: PAI-1 ( $1.4 \mu \mathrm{M})$ was incubated with and without P1-P14 peptide $(110 \mu \mathrm{M})$ for 15 min followed by centrifugal ultrafiltration to separate free peptide. PAI-1 activity was determined before and after filtration. $(C)$ Vitronectin-bound PAI-1: PAI-1 was incubated with vitronectin $(1.7 \mu \mathrm{M})$ for $30 \mathrm{~min}$ at $37^{\circ} \mathrm{C}$ before the addition of P1-P14 peptide, followed by the determination of PAI-1 $t_{1 / 2}$. $\square$, PAI-1 + vitronectin; $\mathbf{a}, \mathrm{PAI}-1+$ vitronectin + peptide.

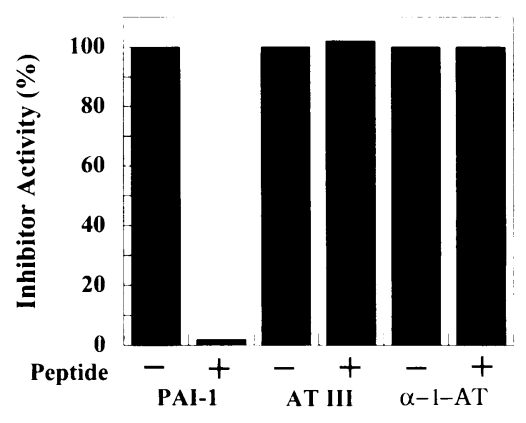

Figure 2. Effect of P1$\mathrm{P} 14$ peptide on other serpins. PAI-1 $(0.7 \mu \mathrm{M})$, antithrombin III ( AT III) $(0.7 \mu \mathrm{M})$, or $\alpha$-1-antitrypsin $(\alpha-1-\mathrm{AT})(0.7$ $\mu \mathrm{M})$ was incubated with P1-P14 peptide $(55 \mu \mathrm{M})$ or buffer for $15 \mathrm{~min}$ at $37^{\circ} \mathrm{C}$, followed by the addition of corresponding protease and substrate as previously described.

ment with P1-P14 peptide (Fig. 3). In contrast to previous studies with other serpins, SDS-PAGE analysis of the products of reaction of t-PA with P1-P14-treated PAI-1 did not reveal increased amounts of cleaved PAI-1, indicating that the peptide did not convert PAI-1 to a substrate form (26).

Effect of Pl-Pl4 peptide on in vitro clot lysis. To determine the capacity of the PAI- 1 peptide to accelerate fibrinolysis, an in vitro clot lysis assay was performed. In the presence of PAI1, clot lysis at $60 \mathrm{~min}$ was accelerated from $28 \pm 7 \%$ to $90 \pm 6 \%$ by the addition of $\mathrm{P} 1-\mathrm{P} 14$ peptide (Fig. $4 \mathrm{~A}$ ), while no augmentation of fibrinolysis by $\mathrm{P} 1-\mathrm{P} 14$ peptide was observed in the absence of PAI-1 (Fig. $4 \mathrm{~A}$ ). Similarly, the control peptide had no significant effect on clot lysis. Furthermore, the degree of clot lysis was proportional to peptide concentration (Fig. $4 \mathrm{~B}$ ). Since platelets are rich in PAI-1 (27) and platelet-rich thrombi are resistant to t-PA-mediated clot lysis (28), the effect of peptide on lysis of platelet-rich clots was also assessed. The lysis of platelet-rich clots at $90 \mathrm{~min}$ was increased from $8 \pm 3 \%$ to $41 \pm 12 \%$ by the addition of Pl-P14 peptide (Fig. $4 C$ ).

\section{Discussion}

The results of these studies indicate that a tetradecapeptide corresponding to the $\mathrm{P} 1-\mathrm{P} 14$ sequence of PAI-1 is capable of rapidly inactivating PAI-1 and augmenting fibrinolysis in vitro. Although the plasma clearance of PAI-1 is relatively short (12,

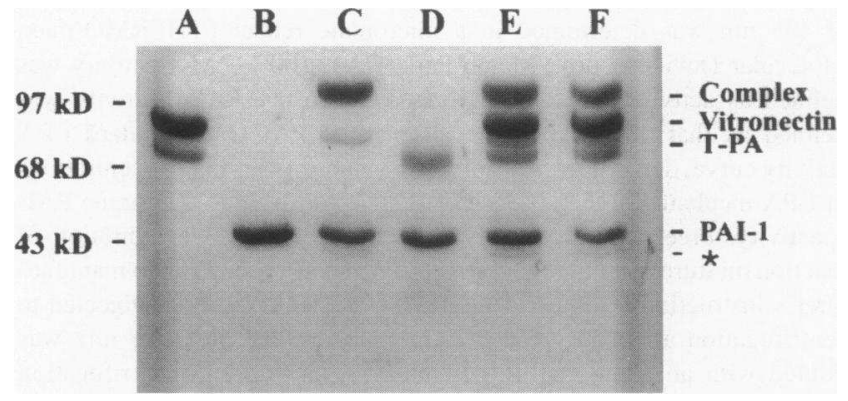

Figure 3. SDS-PAGE analysis of PAI-1-P1-P14 interaction. PAI-1 (5 $\mu \mathrm{M})$, either free or preincubated with vitronectin $(9.7 \mu \mathrm{M})$, was incubated with either P1-P14 or control peptide $(0.5 \mathrm{mM})$ for $15 \mathrm{~min}$ at $37^{\circ} \mathrm{C}$, followed by the addition of t-PA $(3.7 \mu \mathrm{M})$. Reaction products were analyzed by SDS-PAGE under reducing conditions. Lane $A$, vitronectin; lane $B$, PAI-1; lane $C$, PAI-1 + control peptide; lane $D$, PAI-1 + P1-P14 peptide; lane $E$, vitronectin-bound PAI-1 + control peptide; lane $F$, vitronectin-bound PAI-1 + P1-P14 peptide. *Electrophoretic mobility of the cleaved form of PAI-1. 

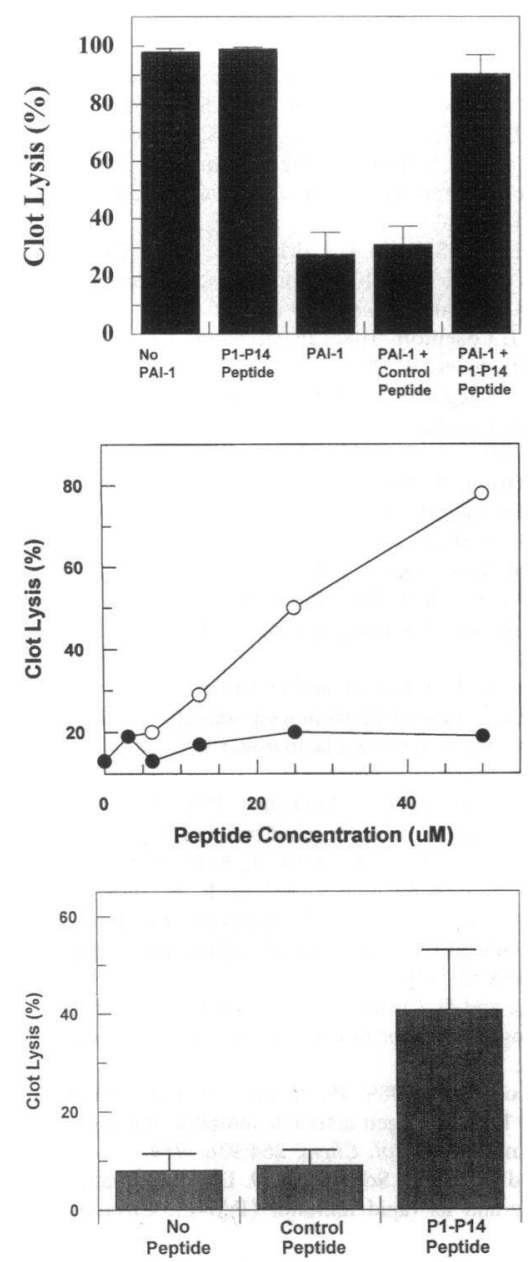

Figure 4. Acceleration of clot lysis by peptide. $(A)$ Platelet-poor clots consisting of fluorescein-labeled fibrin $(3 \mu \mathrm{M})$, gluplasminogen $(0.2 \mu \mathrm{M})$, t-PA (30 nM), PAI-1 $(0.7 \mu \mathrm{M})$, and control or P1-P14 peptide ( $55 \mu \mathrm{M}$ ) were incubated at $37^{\circ} \mathrm{C}$ for $60 \mathrm{~min}$, after which percent clot lysis was determined as described in Methods. (B) Effect of peptide concentration on percent clot lysis at 60 min. O, P1-P14 peptide; -, control peptide. $(C)$ Platelet-rich clots were formed in the presence of P1-P14 or control peptide and percent clot lysis was measured at $90 \mathrm{~min}$.

29), the clearance of PAI-1 from thrombi and the extravascular compartment is likely to be much longer $(7,30)$. The rapidity with which the P1-P14 peptide inactivates PAI-1 may be of potential clinical importance. PAI-1 levels are elevated in young survivors of myocardial infarction (3), and a diurnal variation in PAI-1 levels corresponds to the diurnal pattern of myocardial infarction (31). In addition, PAI-1 mRNA levels are elevated in atherosclerotic arteries (32), and PAI-1 levels in plasma are positively correlated with the risk of recurrent myocardial infarction (33). Hence, this peptide approach may provide a practical method to approach acute and possibly chronic suppression of PAI-1 activity in vivo.

Our results are consistent with previous studies performed with $\alpha$-1-antitrypsin and antithrombin III $(17,18)$. X-ray crystallographic analysis of $\alpha$-1-antitrypsin indicates that, upon cleavage of the reactive center bond, the P1-P14 loop inserts as a new strand into $\beta$-sheet $\mathrm{A}$ (18). In addition, a synthetic tetradecapeptide consisting of the same stretch of amino acids has been shown to form serpin-peptide complexes with physical properties similar to those of cleaved $\alpha$-1-antitrypsin (18), suggesting that the peptide can intercalate into the inhibitor and induce a conformational change that results in serpin inactivation. Studies with antithrombin III produced similar results (17). The inactivation of PAI-1 by P1-P14 peptide is much more rapid than the inactivation of $\alpha$-1-antitrypsin or antithrombin III by analogous peptides $\left(t_{1 / 2}\right.$ of $4 \mathrm{~min}$ vs $>1 \mathrm{~h}$ at $37^{\circ} \mathrm{C}$ ), and this loss of activity is still evident after filtration of the
PAI-1 - peptide mixture to remove free peptide (Fig. $1 \mathrm{~B}$ ). In addition, thermal denaturation studies of peptide-treated PAI-1 indicated the melting temperature to be similar to latent PAI-1 (data not shown). The rapidity with which PAI-1 is inactivated by its P1-P14 peptide may reflect its tendency to assume a latent conformation spontaneously. Unlike antithrombin III and $\alpha$ 1-antitrypsin, however, the substrate form of PAI-1 was not generated after incubation with P1-P14 (Fig. 3), suggesting an alternative mechanism of PAI-1 inactivation (Francis-Chmura, A. M., et al., unpublished observations). Our data suggest the induction of the latent form of PAI-1 by the P1-P14 peptide.

The activities of $\alpha$-1-antitrypsin, the most abundant serpin in plasma, and antithrombin III, the major regulator of thrombin activity, were not affected by the P1-P14 peptide, demonstrating specificity of the peptide for PAI-1 (Fig. 2). This latter observation is particularly relevant as peptide inhibition of antithrombin III could lead to a procoagulant state in vivo. Though we have shown that the PAI- 1 reactive center loop sequence is specific for PAI-1, the capacity of serpins to be inhibited by peptides corresponding to the reactive center loop of foreign serpins has not been previously studied $(17,18)$. Thus, it remains possible that other serpin reactive center loop peptides could demonstrate inhibitory activity towards PAI-1.

It is of note that the P1-P14 peptide is capable of inactivating PAI-1 in the environment of a platelet-rich clot, which contains both fibrin and vitronectin (Fig. 4, $A$ and $C$ ). These ligands probably play important roles in modulating PAI-1 function in vivo $(9,10)$. Vitronectin is present in platelets and plasma and binds PAI-1 with high affinity $(34,35)$. In addition, vitronectin stabilizes the active conformation of PAI-1, prolonging the $t_{1 / 2}$ $\sim$ twofold in solution and up to $24 \mathrm{~h}$ within the extracellular matrix $(25,30)$. The stabilization of PAI-1 by vitronectin has been hypothesized to result from restriction of PAI- $1 \beta$-sheet $A$, interfering with the reactive center loop insertion that is required for PAI-1 conversion to latency (36). Consistent with this hypothesis, PAI-1 bound to vitronectin was highly resistant to peptide inhibition. However, the peptide was capable of accelerating clot lysis despite the presence of vitronectin in platelet-rich clots (Fig. $4 C$ ). We do not have an explanation for this paradox. It may be that, compared to vitronectin, the peptide reacts more readily with PAI-1 in the environment of a clot. PAI-1 also binds to fibrin (10), although with lower affinity than vitronectin, and it has been suggested that fibrin may serve to localize PAI-1 to actively forming thrombi $(10,37)$. However, under the experimental conditions used in these studies, the P1-P14 peptide nearly completely inhibited PAI-1 function in the presence of fibrin (Fig. $4 \mathrm{~A}$ ).

Since elevated PAI-1 levels are associated with thrombosis, inhibition of PAI-1 may be a potentially useful therapy in preventing thrombosis. In addition, since platelet-rich thrombi contain markedly elevated levels of PAI-1 (38) and PAI-1 contributes to the resistance of platelet-rich clots to lysis with $\mathrm{t}$ PA (21), inhibition of PAI-1 may prove useful in augmenting thrombolysis, as suggested by previous studies with anti-PAI1 antibodies $(14,37)$. The larger volume of distribution of small peptides compared to antibodies might enhance the applicability of PAI-1 inactivation, potentially extending its use to in vivo settings. As the plasma concentration of PAI-1 is $\sim 8-$ $32 \mathrm{ng} / \mathrm{ml}$ (39), obtaining peptide/PAI-1 ratios similar to those in our experiments (i.e., 80-fold molar excess of P1-P14 over PAI-1) could be easily attained in vivo. Furthermore, P1-P14 
could provide a powerful model for the rational design of novel, nonprotein inhibitors of PAI-1 function.

\section{Acknowledgments}

This work was supported by a Department of Veterans Affairs Medical Research Service Advisory Group grant (W. P. Fay), and by National Institutes of Health grants HL-09104 (D. T. Eitzman), HL-02728 (W. P. Fay), HL-39137 (D. Ginsburg), HL-08572 (D. A. Lawrence), HL-45930 (J. D. Shore), and HL-39888 (S. T. Olson). D. Ginsburg is a Howard Hughes Medical Institute investigator.

\section{References}

1. Loskutoff, D. J., M. Sawdey, and J. Mimuro. 1989. Type 1 plasminogen activator inhibitor. Prog. Hemostasis Thromb. 9:87-115.

2. Fay, W. P., A. D. Shapiro, J. L. Shih, R. R. Schleef, and D. Ginsburg. 1992. Complete deficiency of plasminogen-activator inhibitor type 1 due to a frame-shift mutation. N. Engl. J. Med. 327:1729-1733.

3. Hamsten, A., B. Wiman, U. de Faire, and M. Blombäck. 1985. Increased plasma levels of a rapid inhibitor of tissue plasminogen activator in young survivors of myocardial infarction. N. Engl. J. Med. 313:1557-1563.

4. Wiman, B., and A. Hamsten. 1990. The fibrinolytic enzyme system and its role in the etiology of thromboembolic disease. Semin. Thromb. Hemostasis. 16:207-216.

5. Carmeliet, P., J. M. Stassen, L. Schoonjans, B. Ream, J. J. van den Oord, M. De Mol, R. C. Mulligan, and D. Collen. 1993. Plasminogen activator inhibitor1 gene-deficient mice. II. Effects on hemostasis, thrombosis, and thrombolysis. J. Clin. Invest. 92:2756-2760.

6. Vassalli, J.-D., A.-P. Sappino, and D. Belin. 1991. The plasminogen activator/plasmin system. J. Clin. Invest. 88:1067-1072.

7. Loskutoff, D. J. 1991. Regulation of PAI-1 gene expression. Fibrinolysis. 5:197-206.

8. Gelehrter, T. D., and R. Sznycer-Laszuk. 1986. Thrombin induction of plasminogen activator-inhibitor in cultured human endothelial cells. J. Clin. Invest. 77:165-169.

9. Keijer, J., H. J. Ehrlich, M. Linders, K. T. Preissner, and H. Pannekoek. 1991. Vitronectin governs the interaction between plasminogen activator inhibitor 1 and tissue-type plasminogen activator. J. Biol. Chem. 266:10700-10707.

10. Reilly, C. F., and J. E. Hutzelmann. 1992. Plasminogen activator inhibitor1 binds to fibrin and inhibits tissue-type plasminogen activator-mediated fibrin dissolution. J. Biol. Chem. 267:17128-17135.

11. Hekman, C. M., and D. J. Loskutoff. 1985. Endothelial cells produce a latent inhibitor of plasminogen activators that can be activated by denaturants. $J$. Biol. Chem. 260:11581-11587.

12. Vaughan, D. E., P. J. Declerck, E. Van Houtte, M. De Mol, and D. Collen. 1990. Studies of recombinant plasminogen activator inhibitor-1 in rabbits. Pharmacokinetics and evidence for reactivation of latent plasminogen activator inhibitor-1 in vivo. Circ. Res. 67:1281-1286.

13. Mottonen, J., A. Strand, J. Symersky, R. M. Sweet, D. E. Danley, K. F. Geoghegan, R. D. Gerard, and E. J. Goldsmith. 1992. Structural basis of latency in plasminogen activator inhibitor-1. Nature (Lond.). 355:270-273.

14. Levi, M., B. J. Biemond, A.-J. van Zonneveld, J. Wouter Ten Cate, and H. Pannekoek. 1992. Inhibition of plasminogen activator inhibitor-1 activity results in promotion of endogenous thrombolysis and inhibition of thrombus extension in models of experimental thrombosis. Circulation. 85:305-312.

15. Marder, V. J. 1992. Inhibiting the inhibitor. Circulation. 85:386-387.

16. Huber, R., and R. W. Carrell. 1989. Implications of the three-dimensional structure of alpha 1-antitrypsin for structure and function of serpins. Biochemistry. 28:8951-8966.

17. Björk, I., K. Ylinenjärvi, S. T. Olson, and P. E. Bock. 1992. Conversion of antithrombin from an inhibitor of thrombin to a substrate with reduced heparin affinity and enhanced conformational stability by binding of a tetradecapeptide corresponding to the $P_{1}$ to $P_{14}$ region of the putative reactive bond loop of the inhibitor. J. Biol. Chem. 267:1976-1982.

18. Schulze, A. J., U. Baumann, S. Knof, E. Jaeger, R. Huber, and C. Laurell.
1990. Structural transition of $a_{1}$-antitrypsin by a peptide sequentially similar to b-strand s4A. Eur. J. Biochem. 194:51-56.

19. Carrell, R. W., D. L. Evans, and P. E. Stein. 1991. Mobile reactive centre of serpins and the control of thrombosis. Nature (Lond.). 353:576-578.

20. Sherman, P. M., D. A. Lawrence, A. Y. Yang, E. T. Vandenberg, D. Paielli, S. T. Olson, J. D. Shore, and D. Ginsburg. 1992. Saturation mutagenesis of the plasminogen activator inhibitor-1 reactive center. J. Biol. Chem. 267:75887595 .

21. Fay, W. P., D. T. Eitzman, A. D. Shaprio, E. L. Madison, and D. Ginsburg. 1994. Platelets inhibit fibrinolysis in vitro by both plasminogen activator inhibitor1 dependent and independent mechanisms. Blood. 83:351-356.

22. Lawrence, D. A., and D. J. Loskutoff. 1986. Inactivation of plasminogen activator inhibitor by oxidants. Biochemistry. 25:6351-6355.

23. Eitzman, D. T., L. Chi, L. Saggin, R. S. Schwartz, B. R. Lucchesi, and W. P. Fay. 1994. Heparin neutralization by platelet-rich thrombi. Role of platelet factor 4. Circulation. 89:1523-1529.

24. Lawrence, D. A., S. T. Olson, S. Palaniappan, and D. Ginsburg. 1994 Engineering plasminogen activator inhibitor-1 (PAI-1) mutants with increased functional stability. Biochemistry. 33:3643-3648.

25. Declerck, P. J., M. De Mol, M. C. Alessi, S. Baudner, E.-P. Pâques, K. T. Preissner, G. Müller-Berghaus, and D. Collen. 1988. Purification and characterization of a plasminogen activator inhibitor 1 binding protein from human plasma. J. Biol. Chem. 263:15454-15461.

26. Declerck, P. J., M. De Mol, D. E. Vaughan, and D. Collen. 1992. Identification of a conformationally distinct form of plasminogen activator inhibitor-1, acting as a non-inhibitory substrate for tissue-type plasminogen activator. J. Biol. Chem. 267:11693-11696.

27. Erickson, L. A., C. M. Hekman, and D. J. Loskutoff. 1985. The primary plasminogen-activator inhibitors in endothelial cells, platelets, serum, and plasma are immunologically related. Proc. Natl. Acad. Sci. USA. 82:8710-8714.

28. Jang, I.-K., H. K. Gold, A. A. Ziskind, J. T. Fallon, R. E. Holt, R. C. Leinbach, J. W. May, and D. Collen. 1989. Differential sensitivity of erythrocyterich and platelet-rich arterial thrombi to lysis with recombinant tissue-type plasminogen activator. Circulation. 79:920-928.

29. Colucci, M., J. A. Páramo, and D. Collen. 1985. Generation in plasma of a fast-acting inhibitor of plasminogen activator in response to endotoxin stimulation. J. Clin. Invest. 75:818-824.

30. Mimuro, J., and D. J. Loskutoff. 1989. Purification of a protein from bovine plasma that binds to type 1 plasminogen activator inhibitor and prevents its interaction with extracellular matrix. J. Biol. Chem. 264:936-939.

31. Angleton, P., W. L. Chandler, and G. Schmer. 1989. Diurnal variation of tissue-type plasminogen activator and its rapid inhibitor (PAI-1). Circulation. 79:101-106.

32. Schneiderman, J., M. S. Sawdey, M. R. Keeton, G. M. Bordin, E. F Bernstein, R. B. Dilley, and D. J. Loskutoff. 1992. Increased type 1 plasminogen activator inhibitor gene expression in atherosclerotic human arteries. Proc. Natl. Acad. Sci. USA. 89:6998-7002.

33. Hamsten, A., U. de Faire, G. Walldius, G. Dahlen, A. Szamosi, C. Landou, M. Blombäck, and B. Wiman. 1987. Plasminogen activator inhibitor in plasma: risk factor for recurrent myocardial infarction. Lancet. ii:3-9.

34. Preissner, K. T., S. Holzhüter, C. Justus, and G. Muller-Berghaus. 1989. Identification and partial characterization of platelet vitronectin: evidence for complex formation with platelet-derived plasminogen activator inhibitor-1. Blood. 74:1989-1996

35. Seiffert, D., and D. J. Loskutoff. 1991. Kinetic analysis of the interaction between type 1 plasminogen activator inhibitor and vitronectin and evidence that the bovine inhibitor binds to a thrombin-derived amino-terminal fragment of bovine vitronectin. Biochim. Biophys. Acta. 1078:23-30.

36. Lawrence, D. A., M. B. Berkenpas, S. Palaniappan, and D. Ginsburg. 1994. Localization of vitronectin binding domain in plasminogen activator inhibitor-1. J. Biol. Chem. 269:15223-15228.

37. Braaten, J. V., S. Handt, W. G. Jerome, J. Kirkpatrick, J. C. Lewis, and R. R. Hantgan. 1993. Regulation of fibrinolysis by platelet-released plasminogen activator inhibitor 1: light scattering and ultrastructural examination of lysis of a model platelet-fibrin thrombus. Blood. 81:1290-1299.

38. Potter van Loon, B. J., D. C. Rijken, E. J. P. Brommer, and A. P. C. Van der Maas. 1992. The amount of plasminogen, tissue-type plasminogen activator and plasminogen activator inhibitor type 1 in human thrombi and the relation to ex-vivo lysibility. Thromb. Haemostasis. 67:101-105.

39. Booth, N. A., A. J. Simpson, A. Croll, B. Bennett, and I. R. MacGregor 1988. Plasminogen activator inhibitor (PAI-1) in plasma and platelets. Br. J. Haematol. 70:327-333. 